\title{
THE BASIC MOTION LEARNING MODEL OF SMALL GAME BASED THROWING IN ELEMENTARY SCHOOL
}

\author{
*Gunawan Setiawan, Syamsuramel, Silvi Aryanti \\ Correspondence: Pendidikan Jasmani dan Kesehatan, Universitas Sriwijaya, \\ Palembang, Indonesia \\ E-mail: gunawan.setiawan2021@gmail.com
}

\begin{abstract}
This study aims to develop a small game-based basic motion learning model at Elementary School Number 65 Rejang Lebong. The research method used is research and development $(R \& D)$ using ten stages from Borg and Gall. The research instruments used were locomotor, non-locomotor tests, and manipulative basic movement skills tests. The treatment in this study was in the form of a basic motion learning model based on small games given for 4 weeks. The subjects in this study were students in grades 4 and 5 of Elementary School Number 65 Rejang Lebong. Subjects in this study were 30 people. The validation results obtained in small-scale trials regarding the quality of the learning model have entered into the validation criteria filled by the validator with a percentage of $63 \%$ and the results of large group trials are declared valid with a percentage of $81.25 \%$ which means very feasible. Furthermore, the effectiveness test was carried out using the t-test. In the significance test of the difference using the SPSS tool, the mean value $=0.8666$ which shows the difference between the pretest and post-test results, the results of $T$-count $=13.730, d f=29$, and $P$-Value $=$ $0.000<0.05$, which means that there are There is a significant difference between before and after being treated with the small game-based learning model of throwing basic motion learning. Where the post-test results have positive results with a significant difference compared to the pre-test results. So that the learning model of the basio motion of throwing based on small gamesccanbe used in learning physical education and health in elementary schools. The implication of this research is that the basic motion learning model of throwing based on small games can be used as a form of learning the basic motion of throwing in elementary school children.
\end{abstract}

\section{Keywords: Learning Model, Basic Motion of Throwing, Small Game}

\section{Introduction}

Physical education is a tool to achieve educational goals, or an education through the adaptation process of physical activities such as organs, neuromuscular, intellectual, social, cultur, emotional, and ethical (Iyakrus, 2019: 169). Athletics as one of the learning materials in physical education taught from elementary school to college. Because athletics is the parent or mother of the sport. Where all sports adopt the movement of athletic movements. Where physical education is an integral part of educational activities as a whole. 
Education plays an important role in preparing for the future of the nation, even the progress of one nation depends on the advancement of education, including physical education, which is able to form a whole human being, namely to form a healthy human being physically and spiritually. In accordance with the motto of Socrates "men sana in corpore sano" which means a healthy body will dwell a strong soul.

Learning of physical education and health begins from early childhood education, then continues kindergarten (kindergarten) then elementary school (SD) as an early education, then continues throughout life ( Sukirno, 2018: 3). Learning is the process of student interaction with teachers and involves learning resources that have been prepared programmatically in the learning environment, learning is a transfer of science that will lead to changes in affective, cognitive, and psychomotor aspects that tend to settle. This process will last a lifetime or a lifetime. Education is inseparable from the role of teachers as managerial, motivators and facilitators who are directly involved in the teaching and learning process. The challenge of teachers in the future will be more difficult where they have to provide opportunities to children according to what is needed by students and not what the teacher wants, because students have different characters, of course the needs of each student are also different.

The development of elementary school children is an important concern because at this stage physical growth either directly or indirectly will affect the motivation of students to learn. Physical development is influenced by motion skills where for anyone who is able to optimize motion, it will be better to maximize the function of sensing so that it can implement the results of sensing to apply the experience in the form of science provided and can be absorbed well and optimally.

According to the results of previous research on the development of gamebased altetic learning models in elementary schools (Sukirno and Reza.R.P, 2018), namely game-based athletic learning there are still some shortcomings, especially in parts of the game where the previous games only explained the stages of play without the purpose of the game, because in a game that is most important is the existence of a clear goal, one of which creates a victory in a game that is explained also according to Patty, A.M (2011: 3) a game creates a comparative atmosphere and competition, from a game there must be a win and lose, the game also aims to create victory (results) and excitement for someone. So researchers want to redevelop a basic motion-based throw small game and create a game that has a goal achieved in accordance with the stages or ways of playing, with a clear goal of creating a victory both individually and a team in a game, then the spirit / enthusiasm of students will be increased because they are trying to find a victory in a game, so that students are more active and more creative and can create better cooperation.

Based on this, effectiveness tests were conducted on products developed especially on the basic motion of throwing based on the small game of public Elementary School Number 65 Rejang Lebong. 


\section{Method}

This type of research uses research and development (R\&D). According to Borg and Gall quoted sugiyono (2017: 28), Research and development is a method used in terms of validating and developing a new product. Validating a product means it already exists and is made into a new product and researchers only test the effectiveness of the product and validate the new product.

The steps in this study use ten (10) stages as follows:

Figure 1. Research Steps

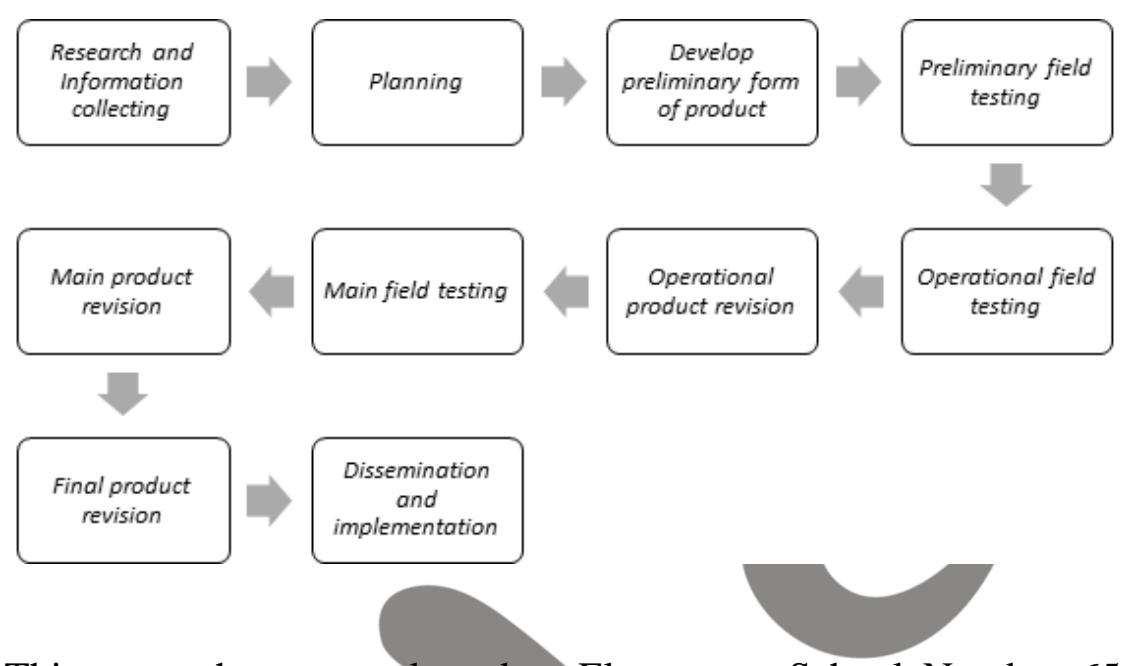

This research was conducted at Elementary School Number 65 Rejang Lebong, Rejang Lebong district. The implementation time of the study is for 6 (six) weeks, namely on January 11, 2021 to February 20, 2021. The population of this study is students of Elementary School Number 65 Rejang Lebong and those sampled in the study are grade 4 and grade 5 students of Elementary School Number 65 Rejang Lebong.

The data analysis techniques are carried out as follows:

1. Establish a reséarch subject groutipn, Health and Recreation

2. Carrying out pre-tests

3. Try out the game model

4. Carrying out post-test

5. Look for the average score of pre-test and post-test results and then compare the two with the help of SPSS.

\section{Results and Discussion \\ Results}

After conducting trials of small groups and large groups followed by conducting model effectiveness tests. This effectiveness test is conducted to find out how effective the model developed against the purpose of research. Effectiveness of the model using pre-experimental research design in the form of "one grup pretest-posttest design".

The steps taken are as follows: 
1. Establish the subject of the research group

2. Carrying out pre-tests

3. Try a small game-based basic motion learning model at Elementary School Number 65 Rejang Lebong

4. Post-test

5. Find out the difference between the two averages through statistical methods with t-test (using spss) to see if there is a significant influence on the use of the developed model.

The results of the model effectiveness test used in this study is to conduct a learning test against Elementary School Number 65 Rejang Lebong using grades 4 and 5 with the number of children involved, namely 30 children given treatment using a small game-based basic motion learning model. Conducted during 4 meetings. The results of the group of pre-test and post-test groups are as follows:

Table 1. Paired Samples Statistic Pre-Test and Post-Test

\begin{tabular}{lll|l|l|l} 
& & & & \multicolumn{2}{l}{ Std. Error } \\
& & Mean & $\mathrm{N}$ & Std. Deviation & Mean \\
\hline Pair 1 & PRE TEST & 2.2667 & 30 & .90719 & .16563 \\
\cline { 2 - 6 } & POST TEST & 3.1333 & 30 & .68145 & .12441 \\
\hline
\end{tabular}

Based on the results of the table above that the average score of the test score based on observation before being given the basic motion learning model of pre-test elementary school children is 2.2667 and after being treated and then done (post-test) is 3.1333. This shows that the basic motion learning model of small game-based throwing deserves to be given or used in elementary school children's learning. So that the objectives that have been determined in this research objective are oriented to the design of development and effectiveness in small games as learning materials for physical edugation and health in elementary schools are achieved.

Table 2. Paired Samples Pretest and Post test

\begin{tabular}{|c|c|c|c|c|c|c|c|c|c|}
\hline & & & & Paired Samp & s Test & & & & \\
\hline & & & & Paired Differe & & & $\mathrm{T}$ & Df & $\begin{array}{l}\text { Sig. (2- } \\
\text { tailed) }\end{array}$ \\
\hline & & & Std. & Std. Error & $\begin{array}{r}95 \% \text { Cor } \\
\text { Interva } \\
\text { Differ }\end{array}$ & $\begin{array}{l}\text { dence } \\
\text { f the } \\
\text { ice }\end{array}$ & & & \\
\hline & & Mean & Deviation & Mean & Lower & Upper & & & \\
\hline Pair & $\begin{array}{l}\text { PRE TEST - } \\
\text { POST TEST }\end{array}$ & -.8666 & .34575 & .06312 & -.99577 & -.73756 & 13.730 & 29 & .000 \\
\hline
\end{tabular}

In the significance test in the difference using SPSS obtained Mean = 0.8666 shows the difference between pre-test and post-test, thitung results = 13,730 , $\mathrm{df}=29$, and P-Value $=0.000<0.05$ which means there is a significant difference between before and after the implementation of the small game-based 
basic throwing learning model. Where hsil from post-test has positive results with significant differences compared to pre-test results. So that the basic motion learning model of small game-based throwing can be used in physical education and health learning in Elementary School Number 65 Rejang Lebong.

\section{Discussion}

This development research is conducted based on several stages conducted by involving several validators who are experts in their field, the stage starts from seeing potential problems, collecting information, designing products, conducting product validation, conducting trials and finally making the final product.

According to Nusa Putra (2013: 67), research and development is a research method that is deliberately done, systematically, aims to find or find, formulate, improve, develop, produce, test the effectiveness of products with superior procedures, new, effective, efficient, productive and meaningful. According to Rasagama quoted by Hartati (2018: 6), suggesting research and development is a process or steps to develop an old product into a new one or perfect an existing product.

According to Aurora, (2015: 59), Games are physical or mental activity, spontaneous and aimless, arousing pleasure, pleasure and refreshing. According to Eliasa (2014:200) The game is an activity that has been arranged/in such a way that it is a self-actualization of the preferred activity, through the game can increase confidence, recognition, and also can express yourself, in the learning process then some learning goals can be achieved.

Based on the advice of basic motion test experts and learning experts elementary school children that the model design developed must be clarified how to perform movements and also in the design must be gradual in order to facilitate teachers or children in applying the model developed. According to Trianto (2011: 28) elementary school children's learning is essentially a game, that bermian is learning, where play is an activity that is done repeatedly and creates a sense of pleasure and satisfaction for the child, playing as a means of socializing, getting the opportunity to explore, Express feelings, eatreate and find fun Tearning suggestions, as well as a vehicle for self-introduction and the environment around the child can find life. According to Taufan (2017: 48) said that exercise dominates as the core of activity. The study of motion and about motion became the main menu in sports programs. Sports studies of engineering assessment achievements are very important in the development of basic motion learning models of small game-based throwing is included in the criteria of "good and worth testing" the statement can be proven from the results of the assessment analysis "Good" from the three experts both basic movement experts and elementary school learning experts, as well as in small-scale trial assessments, large-scale trials and field trials or effectiveness.

Based on large-scale trials conducted using grade 4 and 5 students at Elementary School Number 65 Rejang Lebong as many as 20 students with a percentage of $75 \%$ with a category of "Decent" grades, in the research and development of the basic motion learning model of small game-based throwing is feasible to be used in research instrument aids in the future. From the results of 
the data obtained is interpreted according to a predetermined category. This category is taken according to arikunto (2012: 44) that used in this development research is divided into several parts, namely for the value of $<21 \%$ Very Unworthy, $21 \%$ - 40\%Unfit,41\% - 60\%, SimplyLayak61\% - 80\%worth,81\% $100 \%$ Very feasible.

Based on the results of the t-test conducted showed the results of the test significance in the difference by using SPSS obtained Mean $=0.8666$ shows the difference from the pre-test and post-test, thitung results $=13,730$, $\mathrm{df}=29$, and PValue $=0.000<0.05$ which means there is a significant difference between before and after the implementation of the basic motion learning model of small gamebased. Where hsil from post-test has positive results with differences with significant differences compared to pre-test results. So that the basic motion learning model of small game-based throwing can be used in physical education and health learning in Elementary School Number 65 Rejang Lebong.

\section{Conclusion}

Based on the results of the study "Development of Basic Motion Learning Model Throwing Based on Small Game State Elementary School Number 65 Rejang Lebong ", can be declared worthy of use. Based on the results of the t-test conducted showed the results of the test significance in the difference by using SPSS obtained Mean $=0.8666$ shows the difference from pre-test and post-test, thitung results $=13,730, \mathrm{df}=29$, and P-Value $=0.000<0.05$. then there is a significant difference between pre-test and post-test, thus the Ho hypothesis is rejected and the $\mathrm{H} 1$ hypothesis is accepted. H1's statement is that "There are significant differences in the development of a basic motion learning model based on the small game of Elementary School Number 65 Rejang Lebong."

Based on the conclusion of the results of the study can be proven that the product of the basic motion tearning model of throwing based on small games of Elementary School Number 65 Rejang Lebong as a whole is feasible and effective for use in the learning process of physical education and health in elementary schools. Pherefore, the implementation of the findings is a basic motion learning model of small game-based throwing in elementary schools can be considered by teachers, parents as an alternative tool model of motor physical development, especially the basic motion-based throwing of small games.

\section{Suggestion}

The advice in the study of the basic motion learning model of throwing based on the small game of Elementary School Number 65 Rejang Lebong that has been tested for feasibility by basic motion experts and elementary school children's learning experts. After conducting trials on a small or large scale as well as effectiveness tests. So this research can be suggested with the addition of more subjects in Elementary School Number 65 Rejang Lebong or in other schools. Optimizing the facilities and infrastructure in the school to be used as the implementation of learning activities through small games by utilizing the school environment. This learning can be applied in other schools and not only in elementary schools but can be applied in the community. If anyone wants to 
develop further then it can be used as one of the preliminary studies, then the product can be developed not necessarily in an open space.

\section{References}

Aurora. U. (2013). Contributations to The Pyschomotor Development Of Children With Motor Disabilities From The Persepective Of Their Social Intgartion Through Adapted Physical Activites. Journal Of Physical Education and Sport. 13(1); 57-65.

Arikunto, Suharsimi. (2018). Prosedur Penelitian Suatu Pendekatan Praktik. Jakarta : Rineka Cipta

Eva I. Eliasa. (2014). Increasing Values of Teamwark and Responsibility of the students Through games: Integrating Education Charakter in Lectures, Journal prosedia-social nd behavioral science. Prosedia social and behavioral science, 2(1).198-207

Hartati, dkk. (2018). "Merancang Karakteristik Ilmiah Model Pembelajaran untuk Meningkatkan Penguasaan Konsep Ilmu Gizi II Calon Guru Pendidikan Jasmani dan Kesehatan". Jurnal Pendidikan. 6(5), 621-634

Iyakrus, I. (2019). Pendidikan Jasmani, Olahraga Dan Prestasi. Altius : Jurnal Ilmu Olahraga dan Kesehatan, 7(2).

Patty,A.M.(2011). Permainan Untuk Segala Usia. Jakarta: PT.BPK Gunung Mulia

Taufan, Y, J. S. (2017). Penyusunan Instrumen Ketrampilan Gerak Dasar untuk Bermain Kick Ball. Jurnal Seminar Nasional. 4(1), 49-54

Trianto. (2011). Desain Pengembangan Pembelajaran Tematik. Jakarta: Kencana.

Sukirno dkk. (2018). Pengembangan model pembelajaran gerak dasar berbasis permainan tradisional untuk anak usia dini (TK). Palembang: Unsripress

Sukirno dan Reza,R.P (2018) Pengembangan Model Pembelajaran Atletik BerbasiâPermátnañ di Sekotah Dasar! Pâlembang: Unssipress ation

Sugiyono. (2017). Metode Penelitian Pengembangan. Bandung: Alfabeta.

Nusa, Putra. (2013). Research and Development Penelitian dan Pengembangan suatu Pengantar. Jakarta: Rajawali Pres. 